\title{
Investigating the Occupational Health and Safety Practices in High-Rise Building Construction Sites
}

\author{
Agu Ransford Tetteh ${ }^{1}$, Ye Liang ${ }^{2}$ \\ ${ }^{1,2}$ School of Civil Engineering and Architecture, Zhejiang University of Science and Technology, Hangzhou 310023, China
}

\begin{abstract}
Occupational health and safety practices have become a problem in construction sites since some of the employers undermine the safety of their workers on sites which result to a lot be injured during the construction process. This research is to find out how some occupational health and safety practices involving high rise building sites are obey. Safety practices in the construction industries contributes a good way to accidents prevention and reduction. Therefore, this research was done in view of identification and examine some occupational health and safety practices in our construction industries. This study based in the Accra metropolis, Ghana. Data gathering was obtain by questionnaire and data analysis was carried out using ranking method. The findings showed that almost all factors including occupational health and safety practices, unsafe occupational health and safety practices, adherence to occupational health and safety measures, sanctions for non-adherence, health and safety document on hazardous practices, training workshops on health and safety practices, how often training workshops come off, provision of health and safety equipment for workers. Therefore, to promote Health and safety practices in the construction fields and reduce construction accidents on high rise building site, all these factors have to be considered
\end{abstract}

Keywords: Occupational health and safety practices, construction site, high-rise building

\section{Introduction}

Apparently, the construction industry is currently being recognized as a major economic force in Ghana. The construction industry also plays an important and strategic role in supporting the development and the growth of industry in a nation. Ghana, as a developing country, has concentrated in improving the development of the country by having an increasing number of mega projects, some categorized as national projects. These do not include the increasing number of local projects in most cities in the country, since every region has control of the development within its own area. Despite the fact that construction industries are in line with the intensity of the development, many aspects within the construction itself are neglected. Just as important is the safety of the workers during the working time, concerning the occupational safety aspects within construction industry, it is apparent that the implementation of safety best practices is still far from good.

Construction accidents, which often occur, are due to neglecting certain safety regulation despite the presence of government regulation regarding safety. These cases have been going on since the early development of the construction industry. Generally speaking, every case of construction accident involving casualty of an individual or to a number of workers is investigated thoroughly and ironically the matters are finally resolved with conclusion of careless conduct.

\subsection{Motivation for the Study}

Even when the industry has improved, not only in number but also in their scale and which sometimes involves foreign companies where international safety regulations should be applied. As a result, accidents in the construction industry especially on high rise building sites, in spite of everything, are increasing. Construction industry in the nation has always suffered from poor image, for instance, high cost, poor quality and hazardous working condition. Improving safety practice on Ghanaian high rise building construction sites will not be achieved without the concern and involvement of the government. This is because the government has the influence and the highest authority in the making and enforcing of rules and regulations on health and safety. Hence the need for research into the field to come out with the necessary recommendation.

\section{Related Literature}

It is a known fact that the construction site is unsafe and the risks that the workers are subjected to are usual ${ }^{[1]}$. The accidents may cause physical injuries or health illness in long term. The term hazard in this study is defined as anything that can cause harm such as scaffold, excavation, roof work, working from ladders etc. The risk of hazard can lead to a direct injury to the worker at the scene of the accident and can lead to death in the event of serious consequences. However, the risk of disease can only be reported after a long period of time and will lead to illness or death after a certain period of time. In order to ensure a safe and favourable working condition, there are three basic steps that must be brought to the realization; identify the risk, assess and control their risk. Accra as the capital city of the nation has a greater number of the high rise buildings being constructed. This has directed the attention to where the accidents related to high rise building construction would be highly encountered. To enhance the working life of the workers and to drastically reduce the tendency of highly recorded number of construction accidents, these sites need to be assessed of their health and safety practices. These have expressly called for the research on the safety practices on high rise building construction sites in the Accra Metropolis.

Based on the Ghana labour records[2], one can say that

Volume 9 Issue 4, April 2020 www.ijsr.net 


\section{International Journal of Science and Research (IJSR) \\ ISSN: 2319-7064}

ResearchGate Impact Factor (2018): 0.28 | SJIF (2019): 7.583

occupational health and safety practices have become rampant and even expensive to treat in the construction industry. The construction site as seen today is a very dangerous working ground for employees [3]. The introduction of various more complex construction methods and new construction materials has even made the industry more dangerous. The question is, are workers aware of the health and safety measures associated with these methods? The rampant accidents experienced on construction sites makes one wonder if health and safety practices are adopted. The high rise building construction site is an aspect where very severe hazards are experienced by the workers. These hazards do not only include the danger posed by plant and falling objects but also ignorance of workers about safety measures. Many of these workers fall off earlier in their working life either by being incapacitated or resulting in death as a result of the serious health hazards posed by these operations. Safe working environment and safety of workers is one of the major concerns of the Trade Union Congress and the International Labour Organization [3] [5].

The quest for construction managements and governments to reduce the number of accidents and health hazards on the construction sites has made it significant for the researcher to look into the health and safety practices of the high rise building construction sites in the Accra Metropolis. Accidents have become very rampant on construction sites especially on the high rise building sites in Accra. Some result in death or physical deformity. This called for the need to find out the kind of safety practices if any, of the workers and management relating it to the actual measures required of them.

\section{Methodology}

In order to achieve the aims and objectives set for the research, some strategies were used to determine the health and safety practices on high rise building construction sites in the Accra Metropolis.

\subsection{Research Strategy}

In the quest to gather data for the research, the following processes were used:

\subsubsection{Development of Structured Questionnaire}

Questionnaires were designed and developed to cover the objectives of the research based on preliminary survey. Contractors and safety officers were asked to indicate by ticking the health and safety practices on their sites involving high rise building construction. The questionnaire was also to establish how important each practice is to the firms.

\subsubsection{Distribution of Questionnaire}

Questionnaires were distributed to the personnel in charge of safety on the high rise building sites. Out of 10 questionnaires distributed 10 were received. This gives an indication that $100 \%$ of the questionnaires administered were responsive.

\subsubsection{Collection of Data}

Primary source: The data collected were from the field survey. The use of structured questionnaires was also used to gather information in relation to aid the project which was to collect information that can be analyzed and inferences made to produce conclusion about the health and safety practices on the high rise building sites in the Accra Metropolis. The views of safety personnel as well as workers who do the actual construction work on these sites were sought.

Secondary source: Information was gathered on the subject from literature such as books, journals and the internet relating to the subject.

\subsubsection{Sample Size Determination}

The population considered for the project includes all contractors working on high rise building in the Accra Metropolis. The high rise building definition considered here are buildings over five (5) storeys which are currently under construction. The views of contractors working on high rise building as of the time the research is being conducted were sought on the subject. Ten (10) contractors were contacted for their responses. The construction sites that were contacted are tabulated below:

Table 1: High Rise building sites contacted

\begin{tabular}{|l|l|}
\hline CONTRACTOR & SITE(S) \\
\hline Metropolis Development Limited & VILLAGIO-Airport Residential Area \\
H M K Construction & Cantonment \\
M. Barbisotti and Sons & Airport Residential Area \\
China State Hualong Construction & Opposite WAEC office/ Airport Area \\
CADS Contract & Opposite villagio \\
Marina construction company & Airport Residential Area \\
Keyuan construction & Legon \\
Elnental Properties & Cantonment \\
Fridaug Limited & Aviation area (road) \\
Krane Construction & Cantonment \\
\hline
\end{tabular}

\subsubsection{Ranking}

The outcomes were ranked to determine which practices are mostly adopted on the high rise building sites in the Accra Metropolis. The ranking method used in the analysis is stated below:

$P \%=W / 4 Q$ where

$W=$ the total weighting given to each respective factor,

$Q=$ the number in the sample,

$P=$ the weighted percentage

Source $^{[4]}$

\section{Analysis of Data and Discussion}

Field data gathered from the questionnaires that were administered to various firms were analyzed and discussed. The ranking method was used to analyze the field data collected.

\subsection{Field Data Collected}

Some personnel contacted on the high rise building sites with the questionnaire gave their response upon receipt. Others gave their response within some few days. The response rate is shown in Table 4.2 below;

Table 2: Response Rate

Volume 9 Issue 4, April 2020 www.ijsr.net 


\section{International Journal of Science and Research (IJSR) \\ ISSN: 2319-7064}

ResearchGate Impact Factor (2018): 0.28 | SJIF (2019): 7.583

\begin{tabular}{|c|c|c|c|}
\hline Respondents & $\begin{array}{c}\text { Questionnaire } \\
\text { Sent Out }\end{array}$ & $\begin{array}{c}\text { Questionnaire } \\
\text { Received }\end{array}$ & $\begin{array}{c}\text { Percentage } \\
\text { Responsive }\end{array}$ \\
\hline Construction Personnel & 10 & 10 & $100 \%$ \\
\hline
\end{tabular}

\subsection{Results Discussion}

\subsubsection{0ccupational health and safety practices The Ranking Experiment}

As part of the questionnaire, an attempt was made to ascertain the opinion of respondents on the occupational health and safety practices involving the high rise building construction sites. In all thirteen (13) practices were identified and each respondent was asked to rank the practices in order as to which is practiced most on their sites. A weighting method was used to evaluate the result from the survey. Each practice was considered as stated below and their weighting attached:

Table 3 (a): Weighting for $\mathrm{H} \& \mathrm{~S}$ practices

\begin{tabular}{|c|c|c|c|c|}
\hline & MC & F & OC & NP \\
\hline Weighting & 3 & 2 & 1 & 0 \\
\hline
\end{tabular}

$3 \mathrm{MC}+2 \mathrm{~F}+1 \mathrm{OC}+0 \mathrm{NP}=\mathrm{W}$

Where; MC, is the number of times the practice is ticked "Most Common"

$\mathrm{F}$, is the number of times the practice is ticked "Frequently"

$\mathrm{OC}$, is the number of times the practice is ticked "Occasionally"

$\mathrm{NP}$, is the number of times the practice is ticked "Not Practiced"

$\mathrm{W}$, is the weighted score for the practice.

$\mathrm{P} \%=\mathrm{W} / 4 \mathrm{Q}$, Where;

$P$, is the weighted percentage

$Q$, is the total number of questionnaires distributed.

The results of the analysis are shown in Table $3 . b$ below:

Table 3 (b): Occupational Health and safety practices

\begin{tabular}{|c|c|c|c|c|c|c|c|}
\hline Practice & MC & $\mathrm{F}$ & $\mathrm{OC}$ & NP & W & $\mathrm{P} \%$ & Ranking \\
\hline $\begin{array}{c}\text { Wearing or connecting safety } \\
\text { devices }\end{array}$ & 4 & 3 & 1 & 1 & 19 & 47.5 & $4^{\text {th }}$ \\
\hline $\begin{array}{l}\text { Provide health and safety } \\
\text { notices at vantage points }\end{array}$ & 4 & 3 & 1 & 1 & 19 & 47.5 & $4^{\text {th }}$ \\
\hline Insurance to workers & 5 & 1 & 2 & 2 & 19 & 47.5 & $4^{\text {th }}$ \\
\hline Provision of welfare facilities & - & 5 & 5 & 1 & 15 & 37.5 & $7^{\text {th }}$ \\
\hline Inspections & 2 & 7 & 1 & - & 21 & 52.5 & $3^{\text {rd }}$ \\
\hline $\begin{array}{l}\text { Site workshop training for } \\
\text { workers }\end{array}$ & - & 1 & 5 & 4 & 6 & 15 & $9^{\text {th }}$ \\
\hline Employee induction & 2 & 3 & 3 & 2 & 15 & 37.5 & $7^{\text {th }}$ \\
\hline $\begin{array}{c}\text { Reporting and investigating } \\
\text { injuries and accidents }\end{array}$ & 2 & 3 & 4 & - & 10 & 25 & $8^{\text {th }}$ \\
\hline Site hoarding & 7 & 2 & - & 1 & 25 & 62.5 & $1^{\mathrm{st}}$ \\
\hline Keeping health and safety file & 2 & 5 & 1 & 1 & 17 & 42.5 & $5^{\text {th }}$ \\
\hline Correct design of workplaces & 4 & 3 & 1 & 2 & 19 & 47.5 & $4^{\text {th }}$ \\
\hline $\begin{array}{c}\text { Putting health and safety plan } \\
\text { in place }\end{array}$ & 4 & 4 & 2 & - & 22 & 55 & $2^{\text {nd }}$ \\
\hline Employee fitness or drug test & 2 & 4 & 2 & 3 & 16 & 40 & $6^{\text {th }}$ \\
\hline
\end{tabular}

Based on the analysis of the results from the field data collected, Site hoarding was ranked 1st of the occupational health and safety practices involving high rise building construction sites in Accra with a weighted percentage of
$62.5 \%$. Putting health and safety plan in place was ranked 2 nd with a weighted percentage of $55 \%$. Inspections was also ranked 3rd of the practices with a percentage weighting of 52.5\%. Wearing or connecting safety devices, Provide health and safety notices at vantage points, Insurance to workers, were all ranked 4th of the practices with percentage weighting of $47.5 \%$. The others follow in that order.

In summary, the first three most practiced occupational health and safety practices involving high rise building construction in the Accra Metropolis are site hoarding, putting health and safety plan in place and inspections respectively.

\subsubsection{Unsafe Occupational Health and Safety Practices}

The questionnaire also addressed unsafe practices which are common on the high rise building sites. The respondents were asked to rank the unsafe practices in order in which they are practiced on their sites. In all, a total of seven unsafe or hazardous practices were identified. A weighting is assigned to each of the unsafe practices in order to rank them accordingly. Below are the weightings assigned to the various practices

Table 4 (a): Weighting for unsafe $\mathrm{H} \& \mathrm{~S}$ practices

\begin{tabular}{|c|c|c|c|c|}
\hline & MC & F & OC & NP \\
\hline Weighting & 3 & 2 & 1 & 0 \\
\hline
\end{tabular}

The equations used were

$3 \mathrm{MC}+2 \mathrm{~F}+1 \mathrm{OC}+0 \mathrm{NP}=\mathrm{W}$

The ranking method as stated in the previous analysis was used to rank the various practices. Table 4.b shows the analyzed results.

Table 4 (b): Unsafe occupation Health and safety practices

\begin{tabular}{|c|c|c|c|c|c|c|c|}
\hline Unsafe Practice & $\mathrm{MC}$ & $\mathrm{F}$ & $\mathrm{OC}$ & $\mathrm{NP}$ & $\mathrm{W}$ & $\mathrm{P} \%$ & Ranking \\
\hline Working without authority & 1 & - & 1 & 8 & 4 & 10 & $3^{\text {rd }}$ \\
\hline Using defective equipment & - & 1 & 1 & 8 & 3 & 7.5 & $4^{\text {th }}$ \\
\hline $\begin{array}{c}\text { Working without the } \\
\text { appropriate protective } \\
\text { equipment }\end{array}$ & 1 & - & 5 & 4 & 8 & 20 & $1^{\text {st }}$ \\
\hline $\begin{array}{c}\text { Throwing objects from heights } \\
\text { indiscriminately }\end{array}$ & 1 & - & 5 & 4 & 8 & 20 & $1^{\text {st }}$ \\
\hline $\begin{array}{c}\text { Not labeling harmful } \\
\text { substances and danger zones }\end{array}$ & 1 & 1 & 3 & 5 & 8 & 20 & $1^{\text {st }}$ \\
\hline $\begin{array}{c}\text { Untidy working areas and } \\
\text { blocked access routes }\end{array}$ & 1 & - & 4 & 5 & 7 & 17.5 & $2^{\text {nd }}$ \\
\hline $\begin{array}{c}\text { Not reporting dangerous } \\
\text { activities and accidents }\end{array}$ & - & - & 2 & 8 & 2 & 5 & $5^{\text {th }}$ \\
\hline
\end{tabular}

The following rankings were obtained by the researcher after the analysis of the results from the field data collected with the aid of structured questionnaire.

Working without the appropriate protective equipment, throwing objects from heights indiscriminately and not labeling harmful substances and danger zones shared the $1^{\text {st }}$ position of the unsafe practices found on high rise building construction sites with a percentage weighting of $20 \%$. Untidy working areas and blocked access routes was ranked 2 with a percentage weighting of $17.5 \%$. Working without authority was ranked 3 with $10 \%$ percentage weighting.

\section{Volume 9 Issue 4, April 2020}




\section{International Journal of Science and Research (IJSR) \\ ISSN: 2319-7064}

ResearchGate Impact Factor (2018): 0.28 | SJIF (2019): 7.583

\subsubsection{Adherence to Occupational Health and Safety Measures}

The respondents were also required to tick how often the workers at the sites adhere to safety measures, specifically wearing safety equipment. The results were analyzed using the pie chart to get their rate of adherence. $50 \%$ of the respondents answered "always", 20\% answered "frequently", $30 \%$ answered occasionally and none of the respondents of the study answered "never" making up $0 \%$ of the total response. The result of the analysis is shown in Table 5 and pictorially in Figure 5.

Table 5: Adherence to Occupational H \& S Measures

\begin{tabular}{|c|c|c|}
\hline Time Interval & No. of Respondents & Percentage Response \\
\hline Always & 5 & $50 \%$ \\
\hline Frequently & 2 & $20 \%$ \\
\hline Occasionally & 3 & $30 \%$ \\
\hline Never & - & $0 \%$ \\
\hline
\end{tabular}

Adherence to Occupational Health and Safety practices
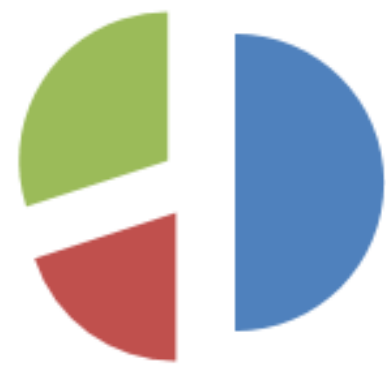

always

frequently

occassionally

never

Figure 5 (a): adherence to $H \& S$ practices

\section{(1)Sanctions for Non Adherence}

As a means of accessing the sanctions faced by workers for non-adherence, the respondents were asked to tick the disciplinary measures taken against their employees for not complying with occupational health and safety measures on the site. $30 \%$ of the respondents answered "dismissal", $10 \%$ answered "salary deduction", none of them answered "suspension", 50\% answered "warning" and $10 \%$ answered "ask them to wear". A detailed analysis is shown in table 6 and shown in a pie chart in figure 6 .

\section{(2)Health and safety document on hazardous practices}

In the quest to establish the adherence of workers and their employers to occupational health and safety practices, the respondents were asked to tick if their company provides major documents on hazardous occupational health and safety practices and materials for the workers to go by. The response gathered is tabulated below:

Table 6: Sanction of non-adherence

\begin{tabular}{|c|c|c|}
\hline Sanctions & No. of Respondents & Percentage Response \\
\hline Dismissal & 3 & $30 \%$ \\
\hline Salary Deduction & 1 & $10 \%$ \\
\hline Suspension & - & $0 \%$ \\
\hline Warning & 5 & $50 \%$ \\
\hline Ask them to wear & 1 & $10 \%$ \\
\hline
\end{tabular}

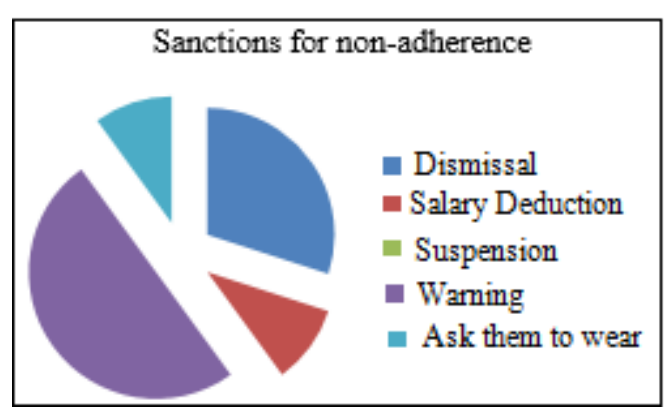

Figure 6: Sanctions for non-adherence

Table 7: Health and Safety document on hazardous practices

\begin{tabular}{|c|c|c|}
\hline Response & No. of Respondents & Percentage Response \\
\hline Yes & 4 & $40 \%$ \\
\hline No & 6 & $60 \%$ \\
\hline
\end{tabular}

Analysis of the response indicated that a higher percentage of the respondents do not have any document pertaining to hazardous practices and substances for their workers to adhere to as guidance when working on the high rise building sites. Six answered "no" carrying $60 \%$ whiles $40 \%$ of the respondents answered "yes" meaning that they have such document.

\section{(3)Training workshops on health and safety practices}

A question was posed to ascertain whether workers were trained pertaining to health and safety practices on site This was to help come out with the rate of adherence to health and safety practices since the training creates the awareness to workers the importance to behave safely.

\section{(4)How Often Training Workshops Come Off}

The respondents were also asked in the questionnaire to indicate how often the site training workshop comes off for their workers if they do provide such to their workers. Five respondents indicated that they offer site workshops for their workers. The data analysis was based on the five respondents. The table below shows the result:

Table 8: Training workshops on Health and Safety practices

\begin{tabular}{|c|c|c|}
\hline Response & No. of Respondents & Percentage Response \\
\hline Yes & 5 & $50 \%$ \\
\hline No & 5 & $50 \%$ \\
\hline
\end{tabular}

The data analysis spelt out the fact that a half of the respondents do train their workers while the other half offers no training to their workers. This gives $50 \%$ to each response.

Table 9: Frequency of workshops/training

\begin{tabular}{|c|c|c|}
\hline Time Interval & No. of Respondents & Percentage Response \\
\hline Monthly & - & $0 \%$ \\
\hline Quarterly & 4 & $80 \%$ \\
\hline Every 6 months & 1 & $20 \%$ \\
\hline Yearly & - & $0 \%$ \\
\hline
\end{tabular}

It can be concluded from the analysis of the results that $80 \%$ of construction firms constructing high rise buildings in the Accra Metropolis who provide health and safety training and workshops to their workers do so quarterly on their sites. On

\section{Volume 9 Issue 4, April 2020} www.ijsr.net 


\section{International Journal of Science and Research (IJSR) \\ ISSN: 2319-7064}

ResearchGate Impact Factor (2018): 0.28 | SJIF (2019): 7.583

the other hand, $20 \%$ of the these firms do so every six months

(5)Provision of health and safety equipment for workers Respondents were also asked in the questionnaire indicate whether they provide safety equipment's or materials to their workers. It was also to establish if the welfare of the workers is ensured on the site. Details of the data analysis are shown in the table below.

Table 10: Provision of H \& S Equipment for Workers

\begin{tabular}{|c|c|c|}
\hline Response & No. of Respondents & Percentage Response \\
\hline Yes & 9 & $90 \%$ \\
\hline No & 1 & $10 \%$ \\
\hline
\end{tabular}

Nine respondents stated that they provide safety equipment to their workers which form $90 \%$ of the total response. A respondent indicated that no safety equipment's are provided to their workers. This takes $10 \%$ of the total response. It is clear from the data analysis that a higher number of the high rise building construction firms in the Accra Metropolis provides safety equipment to their workers on their sites.

\section{Conclusions and Recommendation}

As mentioned in introduction the aim of the research was to identify and rank the health and safety practices on high rise building construction sites in the Accra metropolis and find out the adherence to those practices. Effort to facilitate the achievement of this aim, some conclusions for this research were drawn and recommendations to improve the safety practices in the high rise building construction sites were highlighted.

\subsection{Conclusion}

The occupational health and safety practices involving high rise building construction has been thoroughly searched and identified. The practices have been ranked in their order of frequency and use on the high rise building sites. A conclusion is drawn after the analysis of survey results.

(1)The establishment of Hazards Associated With High Rise Building Construction

As one of the objectives of the research, the researcher has come out with the hazards associated with high rise building construction in general. The established hazards are as follows:

- Slip and fall of persons from heights;

- Crane collapse or crane falls, hoists, etc.;

- Collapse and scaffolding overturning;

- Falling objects;

- Failure to use proper protective equipment;

- Repetitive motion injuries;

- Structure failure; and

(2)The establishment of health and Safety Practices on high rise building Construction

From the preliminary survey, thirteen (13) safety practices were identified and these include:

- Provision of welfare facilities on site;
- Wearing personal protective equipment;

- Employee induction;

- Employee training (site workshops);

- Inspections;

- Reporting and investigating injuries and accidents;

- Insurance to workers;

- Provision of health and safety posters or notices at vantage points;

- Site hoarding;

- Keep the health and safety file;

- Correct design of workplaces;

- Putting health and safety plan in place; and

- Employee fitness or drug test.

(3)The establishment of three (3) most practiced health and Safety Practices in the Accra Metropolis

From the above ranking three (3) most practiced health and safety practices were established and listed in order as follows:

- Site hoarding;

- Putting health and safety plan in place; and

- Inspections.

(4)The Establishment of Unsafe Health and Safety Practices As a result of the research as shown on three (3) most practiced unsafe health and safety practices were identified, ranked equally as 1 st. They are stated below:

- Working without the appropriate protective equipment;

- Throwing objects from heights indiscriminately; and

- Not labeling harmful substances and danger zones.

\section{(5)Adherence to Health and Safety Practices}

The data analysis brought out the fact that most contractors and the workers on high rise building sites adhere to health and safety practices. The respondent opinion established $50 \%$ always adhere to these practices whiles $30 \%$ professed an occasional practice. Most of the safety practices they adhere to have been established as follows:

- Site workshop on health and safety held mostly quarterly on the sites;

- Wearing protective safety equipment;

- Providing health and safety documents on hazardous practices; and

- First aid provision.

Sanctions have been introduced to make sure workers adhere to health and safety practices on the construction sites. The result of the sanctions were analyzed showing that $50 \%$ give verbal warning to the employees whiles $30 \%$ dismiss their workers who do not comply to the health and safety policies of the company.

\subsection{Recommendation}

The researcher has identified few things in the course of the research which when adopted by contractors working on high rise building construction site will improve the safety status of their companies. The researcher recommends that safety practice improvement measures should be adopted by the contractors to improve the working life of their

Volume 9 Issue 4, April 2020 www.ijsr.net 
employees. The recommended improvements include the following:

- Quality Record of Safety and Health Management; Establish standard form for Quality Record Regarding to Safety and Health management;

- Supervisors Capability Improvement; Training program on increasing supervisor's capability in executing work program;

- Recruitment and Certification; Executing safety management certification program; and sending personnel to apply and obtain safety certification; and

- Communication and Reward; Good communication in safety management

The researcher also recommends the establishment of a government agency to supervise and control the implementation of safety practices on high rise building construction sites, generally in Ghana, particularly in the Accra metropolis where there is a fast rate of high rise building development. Such agency, which is given bigger authority to take stern measures and give sanctions to contractors violating the rules is not known or hardly heard of by most contractors. The government should also make specific rules and regulations on health and safety practices and enforce them. These regulations should highlight the need for training of workers before they are employed to work on high rise buildings. They should also make up for compulsory insurance of construction workers especially those working on high rise building sites. Further, the induction of workers should be captured in the regulations to ensure that workers actually fit into areas they are expected to work. In addition, standard safety practices should be laid down by the rules and regulations of which any contractor falling short of it should be prosecuted and punished.

\section{References}

[1] Fales, J. F. (1991), Construction Technology Today and Tomorrow. Macmillan/Mcgraw-Hill

[2] Ghana Labour Records, (2009)

[3] Armstrong, P.T. (1980). Fundamentals of Construction Safety. London: Hutchinson \& Co.

[4] Kometa, S.T., Olomolaiye, P.O. and Harris, F.T (1994), Attributes of U.K Construction clients influence on Project Consultant Performance. Construction Management and Economics, 13(2), (pg137-144)

[5] Occupational Safety and Health Administration- OSHA pocket guide (2005), Worker Safety Series Construction [Online]

www.osha.gov/Publications/OSHA3252/3252.html 